\title{
The Ukrainian Minority in Brno: A Qualitative Research on Ethnic Identity
} TAŤÁNA SOUČKOVÁ

Department of Ethnology and World Studies, University of SS. Cyril and Methodius in Trnava souckova.t@gmail.com

\begin{abstract}
The article focuses on the presentation of the temporary results of the qualitative ethnological research concerning the Ukrainian minority in Brno, Czech Republic. It is aimed on the description of the basic principles of the life of the diaspora in Brno and expressing the ethnic identity of the Ukrainians. After the introductory part author defines the methodological approach as well as the techniques used while carrying out the research. Following part of the article is aimed on characterizing the main attributes of the Ukrainian ethnic identity according to the informants. Moreover, the perception of the presence of the Ukrainian diaspora in Brno is illustrated by the conclusions acquired from the open-ended interviews with the Czech participants.
\end{abstract}

KEY WORDS: Ukrainians, Brno, migration, ethnic identity, Ukrainian culture, Czech Republic

\section{Introduction}

Ukraine and the Ukrainians, these days they are the names mostly associated with terms like conflict, war, international politics and, of course, Russia. Ukraine and its inhabitants have recently become a major topic for people working in a wide range of specializations. There are political scientists analyzing the recent development in Ukrainian crisis and its effect on European politics, there are historians reconsidering the role and position of Ukraine in the east European history and there are also activists organizing humanitarian 
aid for the people in need, not to mention politicians, businessmen, soldiers and many others.

However, it is not only the Ukrainians living in Ukraine, who attract attention. It is also the members of Ukrainian diaspora all over the world being in the spotlight. Speaking about Ukrainian minorities living in other countries, we face the problem of migration and, most importantly, its attributes like ethnic identity and cultural, linguistic and religious assimilation, which are examined by ethnologists. Therefore the main focus of following study is to introduce the Ukrainian minority in the Czech Republic, particularly the part of the diaspora living in Brno, the country's second largest city. The aim of the article is also to present the temporary results and further possibilities of performing field research using qualitative ethnological method. The research focuses also on the ethnicity and its manifestation within the Ukrainian minority group as well as the relations between the majority and the minor ethnic group.

\section{Background of the Problem}

Ukrainian migration to the Czech Republic, or more precisely to the former Lands of the Bohemian Crown, has its long history. According to historical sources, the very beginning dates back to the Early Modern Period, when there can be found information about the presence of the Cossacks coming from today's Ukraine territory. More importantly the migration proceeded during the $19^{\text {th }}$ century, but the most significant period for the Ukrainians in the Czech lands began in 1920s, when the Ukrainian university in-exile called the Ukrainian Free University was transferred from Vienna to Prague. Moreover, in the town of Poděbrady was in 1922 established the Ukrainian Economic Academy, which represented one of the most respected Ukrainian exile academic institutions. The university and the institute were connected with the first wave of the Ukrainian migration. ${ }^{1}$ During the communist period between 1948-1989 the situation, as for the migration from the Soviet Union, was not dramatically changing. The turning point came with the fall of the Soviet Union in 1991, which was followed by the gradual rise in the number of both legal and illegal Ukrainian immigrants in the Czech Republic. This new wave ${ }^{2}$ has had predominantly economic background. The Ukrainians are coming to search for the better paid jobs, as the situation in their mother land is not satisfactory and the possibility of

ZILYNSKYJ, B. (2002): Ukrajinci v Čechách a na Moravě. Stručný nástin dějin. Sdružení Čechů Volyně a jejích přátel, pp. 7-35.

2 Often called „the fourth wave“, see http://www.ukrkonzulat.cz/cz/index.html

DOI: 10.1515/eas-2015-0017 C University of SS. Cyril and Methodius in Trnava. All rights reserved. 
finding a job there is often low or none. Czech Republic is among Ukrainian migrants considered to be a country which is able to offer both work and also the advantage of relatively "fellow Slavic" surroundings.

\section{Research Objectives and Methodology}

Exploring the Ukrainian minority in Brno is a part of wider dissertation project aimed on the Ukrainian diaspora in the Czech Republic and Slovakia. The research will result in the dissertation thesis, which is going to be a comparative study describing not only the present living conditions of the Ukrainian citizens in two major Czech and Slovak cities (Brno and Bratislava), but more importantly their ethnic identity, its preservation and presentation.

Ukrainian minority in the Czech Republic has already been analyzed by various anthropologists, sociologists as well as psychologists, whose concern is intercultural interaction between different ethnic groups. ${ }^{3}$ Articles and monographs aimed on the subject of Ukrainian immigrants are usually oriented on the problems of the economic migration and integration of such immigrants into the Czech society. It is natural, as the Ukrainians are the most numerous ethnic minority in the Czech Republic and the issues of their social inclusion are publicly very well recognized. In spite of the fact that Ukrainian immigrants do not create a homogenous group and their inner social stratification is very diverse, Czech society tends to preserve wide-spread cultural stereotypes about Ukrainians, which are rather negative. However, with the recent affairs in Ukraine, a wide discussion has been in progress in Czech media and among political representatives of the state. Ukraine and the Ukrainian citizens have become a generally discussed topic also for the majority of the Czech society.

From the perspective of an ethnologist are these changes very significant. It is not the aim of ethnology to repetitively analyze the structure of the diaspora or to list

3 BEZOUŠKOVÁ, M. (2012): Východní a západní Ukrajinci v ČR ve vzájemné reflexi. In. Dana Bittnerová, Mirjam Moravcová (eds): Etnické komunity. Kontinuita kulturní reprodukce. Praha: FHS UK, pp. 67-77.; PEŠKOVÁ, M. et al. (2006): Ja-immigrant. Jsem imigrant. Imigranti $z$ bývalých zemí SSSR v České republice. Plzeň: Dryada.; UHEREK, Z. (2004): K změnám identity v prostředí českých měst: migrační skupina $z$ Jižní Ukrajiny. In. Daniel Luther, Peter Salner (eds): Menšiny v meste. Premeny etnických a náboženských identít v 20. storočí. Bratislava, pp. 133-152.; DRBOHLAV, D. (1999): Imigranti $v$ České republice (s důrazem na ukrajinské pracovníky a "západni“ firmy operující v Praze). Online digitalizovaný zdroj dostupný z http://rss.archives.ceu.hu/archive/00001009/01/9.pdf.; RÁKOCZYOVÁ, M., TRBOLA, R. (2009): Sociální integrace pristěhovalců v České republice. Praha: SLON. 
Ukrainian compatriot organizations and their impact on the life of the diaspora. It is also not useful to revise the difficulties of incoming migrants over and over again, and to carry out researches focused on the living conditions of the illegal labourers. Other important and very current questions are to be answered.

Taking into account the fact that we are provided with sufficient information about the present state of the Ukrainian minority in the Czech Republic and the reflection of the interaction with the majority as well, there are other specific issues laying beyond this methodological framework. The problem is simple yet very complex and demands the ethnological rather than the statistical analysis. The crucial topics examined, on the example of the Ukrainian diaspora in Brno, are: Who are the Ukrainians? How do they differ from other ethnic groups and how can be the difference described? What does it mean "to be Ukrainian"?

It is known that nearly half of the Ukrainians, regardless of the place of their recent residence, speak Russian, not Ukrainian. So we must exclude the viewpoint of the language as one of the possible distinctive marks of a particular nation or ethnic group. There are also certain religious differences, since there exist two major churches, the Orthodox Church and the Greek Catholic Church, within Ukraine. The same situation is among Ukrainian immigrants, but still, this cannot be regarded as a distinctive feature of being Ukrainian. Many Ukrainians have traditional connection with Russia, or consider themselves to have Russian ethnic background, as the two states coexisted in one empire for many centuries and there has always been a huge international migration. Moreover, the bonds with Russian culture have become natural as the two nations bear a common tradition of medieval Kievan Rus'.

But then again, how can we capture the true essence of the Ukrainian nation? And does the Czech society recognize it? How is the Ukrainian culture regarded by the Ukrainians and has this ethnic self-awareness changed in order to adjust the cultural surroundings in the Czech Republic? Or is it changing due to the present political situation in Ukraine?

It is recognized that ethnicity does not depend on language, religion, political system or geographical borders. Ethnologists claim that it is more about the common shared awareness of mutual ethnonym, historical experiences, values and aspirations. ${ }^{4}$ For the members of a particular ethnic group is very important sense of togetherness, which is

KAL'AVSKÝ, M. (2004): Etnická identita ako etnologická kategória. In. Ethnologia Actualis Slovaca 5, p. 13

DOI: 10.1515/eas-2015-0017 C University of SS. Cyril and Methodius in Trnava. All rights reserved. 
manifested by participating in common activities, celebrating the same feasts and honouring the same symbols.

In order to decipher the features of the Ukrainian ethnic identity, the ethnologist must apply the proper methodological approach. In the case of examining ethnic awareness and self-identification of individuals it is necessary to have the opportunity to directly communicate with the members of the minority during the fieldwork. Therefore the most convenient method is the qualitative method of ethnological research, especially for this type of research.

In the presented research project following techniques of data collection are used: participant observation, textual analysis, interviews and audio and video recording. ${ }^{5}$ Main focus is put on the interviews with the Ukrainian informers. The interviews are usually informal, although the participant is informed about the purpose of the research and agrees with the terms of the scholar treatment of the acquired data. Interviews can be characterized as open-ended. The interviewee is encouraged to freely speak on the topics, while the researcher is actively listening. However, the interview is still conducted by the researcher, as he asks proper questions having in mind the broader aims of the project. ${ }^{6}$ Apart from the individual interviews also the group interviews take part.

Although some of the interviews are group interviews, there are no focus groups, the informers are chosen from the various possible backgrounds. There are scholar workers as well as people employed in business sphere and since the research is still in progress, we expect to involve also the people from other economic and social backgrounds. We hope to extend the base of the informers by the snowball sampling.

Participant observation is also very important part of the fieldwork and it is closely linked to getting familiar with the events and activities organized by the community. The researcher does not actively participate, but takes part in every possible event trying to understand the purpose and motivation of its organizers as well as the significance of the gatherings for the minority group.

The research project includes also the attitudes of the Czech people and their perception of the presence of the Ukrainians in Brno. There exist widely spread stereotypical ideas about the Ukrainians, but with the recent affairs which have occurred in

SILVERMAN, D. (2006): Interpreting Qualitative Data. Methods for Analyzing Talk, Text and Interaction. London: Sage, pp. 16-17.

lbid. p. 116.

DOI: $10.1515 /$ eas-2015-0017

(c) University of SS. Cyril and Methodius in Trnava. All rights reserved. 
Ukraine, we assume that many Czechs by small degrees reassess their opinion about Ukraine and Ukrainians. This hypothesis is to be verified by the further research.

As was previously stated, the research project analyzing the Ukrainian minority in Brno is in its progress, so the findings are temporary. Nevertheless, there has already been collected interesting and significant data, which we hope to lead to another questions about the Ukrainian (immigrant) ethnic identity and its possible transformations.

\section{The Ukrainians in Brno}

According to the table showing the number of the citizens from the non-EU countries with the permanent or temporary residence in the Czech Republic, most of the Ukrainian immigrants live in the Central Bohemian Region including the capital city of Prague. In the case of Brno, according recent data, there live more than 6000 Ukrainian citizens. ${ }^{7}$ However, generally speaking, estimated number of illegal migrants is much higher. ${ }^{8}$ They mostly work as factory workers or unskilled labourers and their migration can be characterized as circular. These people usually have to deal with so called client system when trying to gain access to the Czech labour market. ${ }^{9}$

Brno is an important center of Ukrainian diaspora. There is a residence of the Ukrainian Consulate, which serves to the Ukrainian citizens from the whole Moravia. Furthermore, there is a branch of study on Masaryk University in Brno, where students achieve their academic degree in specialization named Ukrainian language and literature. By way of studying the Ukrainian language many young Brno citizens get into the first contact with Ukrainian culture and members of the diaspora. Apart from the academic field, there are other visible aspects of Ukrainian presence in the city. Well known is the Ukrainian restaurant Tryzub nearby the city center or a little grocery shop with Ukrainian goods situated also close to the historical center.

As for the public presentation of the diaspora, Ukrainian citizens willing to participate in Brno's cultural life can take part in a festival of the cuisine and culture of ethnic minorities, which is held every year. Ukrainians in Brno, especially those connected with

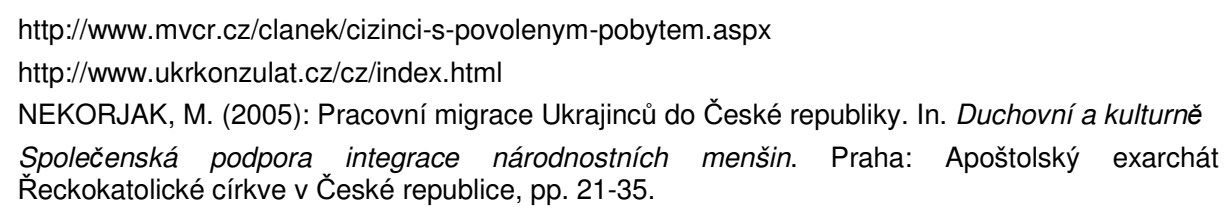

DOI: 10.1515/eas-2015-0017 C University of SS. Cyril and Methodius in Trnava. All rights reserved. 
the Department of Ukrainian language at the university also organize Days of Ukrainian Culture, which are held also in other Czech cities.

However, the Ukrainian minority in Brno is not a homogenous community. According to the interviews with the participants of the research, there are some common places where the majority of the Ukrainians tend to meet, but this fact does not mean that the people maintain close relationships in terms of the whole minority group. The most significant place of common gatherings is the Orthodox Church of Saint Wenceslas. The important authority of the parish is the priest and rector of the church, who is recognized not only among Ukrainians, but among all the orthodox Christians attending the church services. Brno's Orthodox Church is a meeting place for the immigrants from other countries of Eastern Europe, Balkans and Caucasus.

There is also a Greek Catholic parish in Brno, its Church of Saint Joseph was reopened for the public in 2014. Regular church services are conducted in Old Church Slavonic language as well as in Ukrainian language. The Church is attended predominantly by the Ukrainians coming from the Subcarpathian region (Zakarpattia Oblast) or the Western Ukraine, where is Greek Catholic Confession traditionally spread.

According to one of the informants (Anna, 43 years), Ukrainians in Brno form various groups, which are not always aware of each other. In her opinion, some of them are very closed, their members tend to communicate more within the group and less with the Czech people. In many cases they even do not speak the Czech language. It is also probable that inside the diaspora can be distinguished those who belong to the older generation of the migrants and those who came during the past 20 or 25 years. The migrants from the last migration wave, whose purpose of coming to Brno was purely economical, are prone to maintain the relationships based on communication solely with their fellow compatriots. They do not feel the need to study the Czech language or they are not planning to stay in the Czech Republic for more than several months, due to the circular nature of the migration. On the contrary, Anna belongs to those immigrants, who actively learn the Czech language and plan to stay in Brno. So do her friends from Ukraine with whom she keeps in touch.

Anna confirmed that the church is the most important place of gatherings for the Ukrainians, although she personally does not regularly attend the services. Another interviewee, Olha (68 years) also agreed that the Orthodox Church is a center of the religious and cultural life of the diaspora. Many of the migrants do not attend the church every Sunday, but most of the Ukrainians come to celebrate Easter and Christmas. Anna says that Easter is the most important feast of the year and it is also the feast, which 
reminds her the most about Ukrainian folk traditions, which are quite different from the Czech ones. $^{10}$

Other places, like the restaurant Tryzub or the Ukrainian shop do not seem to have importance for the Ukrainians in Brno. They know about the possibility of going there, but all the informers confirmed that when they wish to prepare traditional Ukrainian food, they do not need to buy the ingredients in such a shop. They either bring them directly from Ukraine or use those available in Czech shops. Oksana (40 years) adds that it is well known, that goods sold in that shop are not of pure Ukrainian origin and that visiting the restaurant does not have any sense if they can cook the Ukrainian food themselves.

\section{I am Ukrainian. It is my identity ${ }^{11}$}

When carrying out the research, observing the field and talking to the informants, inevitable questions pop in mind of the researcher. How can we define the Ukrainian identity? These questions occur since the problem of the Ukrainian identity is a very complex one. According to the general theories describing ethnicity, it has nothing to do with the language, religion or the citizenship as was previously stated. ${ }^{12} \mathrm{M}$. Kal'avský argues that it is mainly the common sense of originality of the ethnic group and common aspirations, what forms the ethnical awareness of the group. However, even if we can distinguish such features among Ukrainians, we can still be confused, as their own opinions on the problem significantly vary.

Some of the Ukrainians in Brno speak Russian, like Anna, who comes from the Eastern Ukraine, others speak Ukrainian, but from time to time switch unconsciously into the Russian and back. This is case of Ol'ha (68 years) and her husband, who have been living in the Czech Republic for over 20 years. They speak fluent Ukrainian, but when remembering his youth in Kiev, Ol'ha's husband automatically starts to speak Russian, as his memories are connected with the language.

When asked about the significance of the language, all the interviewed participants of the research agreed that language has no importance as for the sense of belonging to the

10 The most important part of Easter celebrations among the Orthodox Christians is attending the Eastermass, where the traditional meals are sanctified by the priest.

11 http://www.vetrnemlyny.cz/aktuality/97-Vychod-zapad-Jak-jsem-utikala-z-Ukrajiny-na-Ukrajinu

12 LENOVSKÝ, L. (2006): Kontexty identity. In. Ethnologia Actualis Slovaca 6, p. 16 ; KAL'AVSKÝ, M.(1991): Etnicita alebo etnické vedomie? In. Slovenský národopis 3-4, pp. 354-357. 
Ukrainian nation. Among the diaspora members, it is usual, that the communication takes place in the language convenient for the speakers. It can be both Russian and Ukrainian.

However, discussing the language relevance, one exceptional opinion was expressed. Valentina, 36 years old scholar does not support the opinion that the language is not relevant feature of being Ukrainian. She claims that if there exists an official language, people declaring themselves as Ukrainians, regardless on the place of their birth or residence, ought to be able to speak it. "How can they say, that they are Ukrainians, when they speak Russian? I have never understood such a dichotomy. There is something schizophrenic about that", stated Valentina. And, according to her experience, she is not the only one. With the dramatic recent political development in Ukraine, more Ukrainian citizens in Brno start to manifest their ethnic identity by active usage of Ukrainian instead of Russian. Valentina also appreciates the website of Brno City Municipality that is translated into Ukrainian. She says that it is the sign that Brno takes its inhabitants seriously and it means that the Ukrainian minority is being recognized and accepted. "It could have been in Russian, and it would be logical and maybe more convenient, but it is in Ukrainian and I feel honoured by that".

Language has been regaining its importance also for the newly established Ukrainian associations. Before the conflict in Ukraine, the minority was rather passive and not loudly manifesting its ethnicity and pride for their country of origin. With the dramatic development in Kiev and demonstrations taking place on the Independence Square (Maidan Nezalezhnosti) in 2014, many of the Ukrainians living abroad have started to express continual support for the demonstrators. In Brno, such activities were transformed into the founding of the Ukrainian Initiative of South Moravia ${ }^{13}$, whose aim is to bring together the South Moravian Ukrainian minority and to present its culture to the public. Nowadays it is becoming the most visible and significant Ukrainian organization in Brno. The important thing is that the stress is put also on the language. Despite the fact that for many Ukrainians their mother language is Russian, when attending the events organized by the Initiative, only Ukrainian can be heard. Also the Initiative's communication on the social networks takes part in Ukrainian, as it is considered to be a crucial principle of how to define the Ukrainian ethnic identity. We can summarize the message hidden behind these ideas as "I am Ukrainian, because I speak Ukrainian, not Russian. Our nation has its own language, history and unique cultural traditions, which are different from the Russian traditions."

13 http://ukrijm.cz/

DOI: $10.1515 /$ eas-2015-0017

(c) University of SS. Cyril and Methodius in Trnava. All rights reserved. 
Via associations like the Ukrainian Initiative of South Moravia the minority is trying to manifest its uniqueness and to show to the Czech society in what areas are the Ukrainian traditions original. However, not always are the Ukrainian traditions strictly separated from the Russian ones. It is natural, as the two nations come from the common historical background, therefore many symbols and features of the folk culture are similar and often there cannot be drawn a line between Ukrainian and Russian customs. This is also the case of another Ukrainian organization in Brno, the Folklore Association of Friends of Russian and Ukrainian culture "Sudarushka". ${ }^{14}$ The members of Sudarushka perform songs in the Ukrainian language and use the Ukrainian folk costumes as well as the Russian folk costumes and the Russian language, which comes naturally for the members, as they apparently do not feel the need to strongly separate those two folk traditions.

This dilemma of bilinguality and mutual cultural blending is typical for the Ukrainians. In spite of the recent activities of some associations and individuals directed at the specification of Ukrainian culture and its originality, many of the participants of the research claim that the line between the Ukrainians and the Russians is ambiguous and sometimes difficult to understand. As Anna says, it is not the matter of language, religion or culture in many cases, it is about inner feeling of belonging to the Ukrainian nation. Other informants agree with Anna's opinion and their answers to the question on the Ukrainian ethnic identity is clear. "No matter where I live and no matter what language I speak, I am a Ukrainian because I feel like being Ukrainian deep down in my heart", was the reaction of Ol'ha, her husband, Valentina, Oksana as well as other respondents interviewed during the group interview in February 2015. When asked to characterize their ethnic identity, they stated that being Ukrainian means having typical features of Ukrainian social mentality. These attributes, according to the informants, are emotionality, sensitivity, compassion with others, hospitability and sincerity. Valentina and Ol'ha also stated that according to their opinion, Ukrainian people tend to be even excessively sympathetic towards other people, they have no prejudices and are not afraid to be confronted with negative attitudes of others, meaning that they are very patient and open to different ideas and aspirations. As for the negative characteristics, only Valentina mentioned indifference and lack of concern for the public affairs.

Apart from the psychological attributes of the identity, Ukrainians recognize some of the crucial symbols of the folk culture and present state symbols like the Tryzub on the

$14 \quad$ http://sudaruska.webnode.cz/

DOI: 10.1515/eas-2015-0017 C University of SS. Cyril and Methodius in Trnava. All rights reserved. 
State Emblem of Ukraine and the Flag to be the part of the manifestation of the culture and Ukrainian identity.

\section{The Borsch Paradox}

The problem of analyzing the life and present situation of the Ukrainian minority in Brno inseparably involves the reflection of the point of view of the Czech majority. It is generally known that there exist many rather negative stereotypes about Ukrainians. The Ukrainians are seen as social and cultural inferiors usually working illegally in building industry or they are associated with the crime and mafia. ${ }^{15}$ Moreover, due to the fact that many Ukrainians living in the Czech Republic speak Russian, the Czech people fail to distinguish them from the ethnic Russians.

The important part of the presented research is also the perception of the presence of the Ukrainian citizens in Brno. So far, five individual open-ended interviews and one group interview were carried out. When speaking about the level of knowledge about Ukraine and the Ukrainians in general, it is significantly low. Czech people tend to associate Ukraine with Russia, stating, that this is the legacy of the Soviet era. František (28 years) explained that he has no further knowledge about Ukraine, as he can see no genuine difference between Ukraine and Russia. His only experience with the Ukrainians took part during working for a company that employed also Ukrainians, and the experience was negative. It is very typical that the Czechs keep mistaking Ukraine for Russia, especially those, who experienced the Soviet period: "I visited Russia, too, said Helena (62 years), it was in the 80 's, we travelled to Crimea."

Other participants say that they have either no experience concerning the Ukrainians or they are of peripheral importance. Speaking about the Czech reflections on the Ukrainian minority in Brno, the lack of interest about the minority is significant. Jiří (33 years) said that he is not interested in cultural life and presentation of the Ukrainians in Brno simply because he does not get to meet Ukrainians and does not know about any of their cultural events. These are the reasons why he has no specific opinion about the Ukrainians living in the same city as him. He also does not have any motivation to change his attitude, as the problems of Ukrainian minority seem very distant from his daily routines and cultural activities. Very similar opinion was expressed also by the participants of the group

LEONTIYEVA, Y. (2004): Ukrajinci. In. Výzkumná zpráva: Integrace cizinců $v$ ČR. Studie arménské, vietnamské a ukrajinské komunity v Praze a Středočeském kraji. Praha: IOM, p. 27. Dostupné z http://www.iom.cz/files/IntegraceUkrArmVietn_final_PDF1.pdf. 
interview. "I have no interest in the Ukrainian minority in Brno and I do not see any reason, why should I have any", claimed Jana (28 years).

Regardless of the common indifference of the Czech people towards the Ukrainian minority, there is one attribute of the Ukrainian culture which is generally recognized by the Czech public, however, not in the way Ukrainians would like it to be recognized. It can be described as the paradox of borsch. This famous vegetable soup is very popular in the Czech Republic and is commonly offered in restaurants and school canteens. For many Czechs the borsch is "one of the most favourite soups" (František, 28 years). The only problem is that for the most of the Czech people borsch is connected with Russia and they know itby the collocation "Russian borsch". This is also the way it is usually presented in the menus of the restaurants.

However, Ukrainians consider the borsch to be their national, unique and original dish which was created on the territory of Ukraine and belongs to its national cultural heritage. This is the opinion of all the Ukrainian informants and it also confirms the experience of the author of the research, who has already had the opportunity to communicate with the Ukrainians both in the Czech Republic and in Ukraine before conducting the presented research. Ukrainians strongly refuse that the borsch is of Russian origin, though they admit that it is widely spread in Russia as well. Nevertheless, for example, Anna claimed that Russians had their own typical vegetable soup called "shchi" and that she understood why the Czechs associated the borsch with Russia but did not agree with it.

On the contrary, when asked about the origin of the borsch, all of the interviewed Czechs answered that everybody knew that borsch had come from Russia, therefore it was called the Russian borsch. The Czech participants are usually surprised by the information, that Ukrainians have completely different opinion. Only one of the informants, Jiří, knew about the Ukrainian nature of the borsch, since he had the chance to get to know Ukrainians who were working nearby his former residence and prepared borsch for the lunch. From them, he had heard the theory about the origin of this soup.

The example of the perception of the borsch can be transformed into the more general and serious level of describing the intercultural encounters. It is an illustration of indifference of the majority towards the minority, or the tendency to equate two different ethnics alongside with their cultural background. While the Ukrainians living abroad, in this case in Brno, would like the Czech society to understand and to recognize the basic attributes of their culture, even such a symbol as the borsch, the majority society is rather unconcerned, uninterested and without any further motivation to change its attitude.

The temporary results of the qualitative research show that this situation has not dramatically changed in relation with the political development in Ukraine. In order to help 
the Ukrainians in need in Donbas, there were founded various Czech initiatives aimed at the humanitarian activities. ${ }^{16}$ The Lisen Theatre, a small theatre in Brno, cooperates with the Ukrainian Initiative of South Moravia and together they organize meetings, discussions or performances focused on the political development and, most importantly, on the negative impact of the Russian political propaganda. According to the participant observation during these events, it can be concluded that the attendance of the Czech people is rather low, although they take active part in the discussions and are keen to debate on the topics concerning the Ukrainian crisis. However, it can be also stated that the main concern of the Czech society is for the political background of the crisis, as the Czechs feel strong compassion for the fight with the Russians. This attitude has its origin in the historical experience of the Czech people, who tend to refuse everything that comes from Russia, as there is a strong feeling of being endangered by the Russian politics. Majority of the Czech participants of the research express their concern about the recent development in the Eastern Ukraine, stating that they are afraid of the possibility of the outbreak of the war conflict, which would put the Czech Republic in danger. These opinions are also typical for the public discussions about the situation in Ukraine. The crucial question is if this Czech concern for Ukraine and the Ukrainian activities in Brno, or elsewhere within the Czech Republic, is essentially about the will to get to know the country, its inhabitants and culture, or if it is an expression of inner Czech fear of repeating the negative events of the past. In this case, the concern for the Ukrainians would represent only a kind of disguise for the real nature of the Czech attitudes, which would be in fact anti-Russian rather than proUkrainian. However, these assumptions are to be verified during the further qualitative ethnological research carried out both within the Ukrainian minority and the Czech majority.

\section{Conclusion}

The Ukrainian minority in Brno represents the largest ethnic minority in the city and in the Czech Republic in general. For the Czech society, the Ukrainians are connected with rather negative ethnic hetero-stereotypes, although the recent development concerning the public discussion about the conflict in Ukraine has had an impact on the Czech concern for Ukraine and its citizens. Nonetheless, it is questionable what is the real nature of this interest and what is its background for the Czech society. As for the Ukrainian citizens living in Brno, the development in Ukraine was a stimulus for the public presentations of their culture and ethnic identity. Nevertheless, the problem of defining ethnic identity of the

16 https://www.facebook.com/prvnidenproukrajinu; http://www.chutpomahat.cz/

DOI: 10.1515/eas-2015-0017 C University of SS. Cyril and Methodius in Trnava. All rights reserved. 
Ukrainian migrants is very complex, as their opinions and attitudes towards these questions often vary. There can be distinguished several attributes which are common for all the immigrants embodied in the research. They are recognizing and sharing the same mental characteristics, taking part in celebrating the same religious feasts as well as sharing the same awareness of what are the most significant cultural symbols of the nation. On the contrary, most of the interviewed participants claim that language is not the attribute of their ethnicity. They also state that it is very difficult to characterize the essence of being Ukrainian, as the country of their origin is large and the people from different regions of Ukraine can have different aspirations. The significant part of defining the Ukrainian ethnic identity is also distinguishing between "Ukrainian" and "Russian", both from the political, cultural, mental and linguistic point of view.

\section{Bibliography}

BEZOUŠKOVÁ, M. (2012): Východní a západní Ukrajinci v ČR ve vzájemné reflexi. In. Dana Bittnerová, Mirjam Moravcová (eds): Etnické komunity. Kontinuita kulturní reprodukce. Praha: FHS UK, pp. 67-77.

DRBOHLAV, D. (1999): Imigranti $v$ České republice (s důrazem na ukrajinské pracovníky a „západni“ firmy operující v Praze). Online digitalizovaný zdroj dostupný z http://rss.archives.ceu.hu/archive/00001009/01/9.pdf.

KAL'AVSKÝ, M. (1991): Etnicita alebo etnické vedomie? In. Slovenský národopis 3-4, pp. 354-357.

KAL'AVSKÝ, M. (2004): Etnická identita ako etnologická kategória. In. Ethnologia Actualis Slovaca 5.

LENOVSKÝ, L. (2006): Kontexty identity. In. Ethnologia Actualis Slovaca 6.

LEONTIYEVA, Y. (2004): Ukrajinci. In. Výzkumná zpráva: Integrace cizinců $v$ ČR. Studie arménské, vietnamské a ukrajinské komunity v Praze a Středočeském kraji. $\begin{array}{lllll}\text { Praha: } & \text { IOM, } & \text { p. } & \text { Dostupné }\end{array}$ http://www.iom.cz/files/IntegraceUkrArmVietn_final_PDF1.pdf.

NEKORJAK, M. (2005): Pracovní migrace Ukrajinců do České republiky. In. Duchovní a kulturně společenskápodpora integrace národnostních menšin. Praha: Apoštolský exarchát Řeckokatolické církve v České republice, pp. 21-35.

PEŠKOVÁ, M. et al. (2006): Ja-immigrant. Jsem imigrant. Imigranti z bývalých zemí SSSR v České republice. Plzeň: Dryada. 
TAŤÁNA SOUČKOVÁ

The Ukranian Minority in Brno: A Qualitative Research on Ethnic Identity

RÁKOCZYOVÁ, M., TRBOLA, R. (2009): Sociální integrace přistěhovalců v České republice. Praha: SLON.

SILVERMAN, D. (2006):Interpreting Qualitative Data. Methodsfor Analyzing Talk,Text and Interaction. London: Sage.

UHEREK, Z. (2004): K změnám identity v prostředí českých měst: migrační skupina z Jižní Ukrajiny. In. Daniel Luther, Peter Salner (eds): Menšiny v meste. Premeny etnických a náboženských identít v 20. storočí. Bratislava, pp. 133-152.

ZILYNSKYJ, B. (2002): Ukrajinci v Čechách a na Moravě. Stručný nástin dějin. Sdružení Čechů Volyně a jejích přátel, pp. 7-35.

\section{Websites}

https://www.facebook.com/prvnidenproukrajinu

http://www.chutpomahat.cz/

http://www.mvcr.cz/clanek/cizinci-s-povolenym-pobytem.aspx

http://sudaruska.webnode.cz/

http://ukrijm.cz/

http://www.ukrkonzulat.cz/cz/index.html

http://www.vetrnemlyny.cz/aktuality/97-Vychod-zapad-Jak-jsem-utikala-z-Ukrajiny-naUkrajinu 